\title{
City of Clones: Facsimiles and Governance in São Paulo, Brazil
}

\author{
Graham Denyer Willis \\ Department of Politics and International Studies at the University of Cambridge
}

\begin{abstract}
São Paulo, Brazil, is a megacity defined by formal and informal patterns of urbanization. Informally urbanized spaces are not absent of state intent, despite appearances. Rather, the state's apparent absence is itself a form of governance: such populations are decisively left to die. Such abandonment has, paradoxically, given rise to a number of grassroots-led social and spatial practices for survival, agency, and selfgovernance. Even so, these auto-constructed responses and conditions contribute to the reproduction of urban political order in surprisingly unoriginal and routinely recognizable ways. I argue that these unexceptional informal practices can be understood as 'facsimiles' of their formal institutional originals, or counterparts. Using the examples of cloned cars I show that the facsimile and the original are, for all practical purposes, the same in form and function. I further argue that facsimiles do not exist outside of political authority, but are a byproduct and a component of it. The consequence is that the facsimile and the original are indistinguishable in their bureaucratic deployment, recognition and acceptance as part of social and spatial order.
\end{abstract}

Keywords: Governance, Informality, Cities, Brazil, São Paulo

\section{Introduction}

São Paulo, Brazil, is a city defined by formal and informal practices. For every formal service provided by the state-ranging from urban planning, public transportation, economic regulation, security, and so on-there are myriad 'informal' practices and institutions offering the same or similar service. These informal practices and institutions routinely emerge in spaces where the state appears absent. But this 'absence' is a practice of governance. These are spaces where populations are left to die, almost unremarkably, precisely because their subjects have been systematically devalued by the state -if not society more generally (Mbembe 2003; Wacquant 2008; Sarat and Cuthbert 2009). The 
'formal' and the 'informal' exist in relation to each other, where both are mutually produced and bound together by shared practices of power and common assumptions about larger patterns of political authority.

I argue for a consideration of São Paulo as a city of clones where formal institutions and outcomes exist intertwined with informal copies of the same institutions and outcomes. Some such copies are easier to identify vis-à-vis their originals. They are visible, material, as with housing production in informal settlements; while others are more obscured from view, as with everyday policing practices in informal areas. Yet there are still other practices in São Paulo where it quite literally takes a magnifying glass to discern the difference between one and the other. This is the difference between cloned and 'real' cars on the street -and in the bureaucracies that make them possible-, as I will explore. Even where the real and the 'facsimile' appear distinct, or where they appear indistinct, they are nonetheless produced by mutually constitutive practices that bind the formal and informal realms together.

The production of originals and facsimiles has a spatial logic as well, reflecting historical patterns of state-society relations and urbanization processes. Originals operate in spaces of relatively strong state-society relations, where centrally-distributed and governmentmonitored services are more prominent. Facsimiles proliferate in areas where state presence is relatively weak, selective, or even absent. Their emergence can be seen as a mode of survival or adaptation to neglect and the paucity of centrally redistributed services. Urbanization processes further differentiate these governance zones, as state absence and self-governance responses are more likely to exist in the "informally built" periphery than in 
the formally-built center (Roy and Al Sayyad 2004; Roy 2009). Yet despite their spatial differentiation, 'originals' and 'facsimiles' co-exist in the same metropolitan arena.

I argue that while originals and facsimiles may appear distinct in de jure terms, their de facto distinctiveness is neither borne out in everyday life, nor within the larger system of political order. Originals and facsimiles are both subject to routine practices of state bureaucracy in ways that make their everyday production and consumption mundane, unexceptional, and, largely, uncontested. They both exist as functionally equivalent components of the same system of authority in which bureaucratic rationality and legitimate governance are common ideals. In their commonplace existence the facsimile and the original reflect the logic of the city and how urban society is governed, where formal institutions and practices cannot be easily disaggregated from informal institutions and practices.

In what follows, I will discuss an undertheorized kind of facsimiles in São Paulo: the cloning of cars. The cloning of cars occurs at a dizzying scale in São Paulo, where the owners of original cars are unable to find redress from either police or the vehicle registration bureaucracy in asserting formal ownership authority. These activities are woven into a tapestry of bureaucratic practices with those of formal state actors, suggesting that the existence of clones is mundane, unexceptional, unremarkable.

To begin, I provide some background on the research and data that I analysed to reach my conclusion. I then move to a discussion of the theoretical basis for considering how some devalued populations have organized in ways that are central to governance and order. I 
then examine how the cloning of cars replicates a number of governance and bureaucratic functions as though part of the state. I conclude with a brief discussion.

\section{Episteme and Method}

This article is based on fieldwork carried out between 2009 and 2012 alongside homicide and other detectives in neighbourhood and specialized precincts of the Civil Police ${ }^{1}$ in the city of São Paulo. As I have discussed at length elsewhere, during this participant observation research, I focused on the investigative practices, daily routines, and assumptions of detectives as they went about their work, which ranged from filing reports, to visiting and investigating scenes, and liaising with citizens (Denyer Willis 2015). Much of the aim of that research was to understand how detectives monitored or measured citizens movements in space. For homicide detectives, I tracked how they mediated both homicides and the routine police shootings of citizens that characterize the city. In considering patterns of cloning, I draw upon recent media reports, crime testimonies, and government reports to provide a fuller picture of car cloning. For my discussion of police and criminal justice clones, I analysed a trove of internal PCC documents given to me by a contact in the public security system, after the documents were seized from arrested PCC members. Similarly, I augment my analysis by drawing on a variety of media reports, now-public wiretap data, and social media videos.

\section{Space, Urbanization, and Social Practice}

Many cities in the Global South have become famous for their stark patterns of urbanization, 'slum' conditions, and dramatic housing inequalities (Davis 2004; Roy and Al

\footnotetext{
${ }^{1}$ The Civil Police has many occupational subdivisions.l explain and expand on the differences between these elsewhere (Denyer Willis 2014a ; Denyer Willis 2014b).
} 
Sayyad 2004; Gilbert 2007). In Latin America, the study of informal urbanization and its spatial dynamics and social practices is especially well established (Gay 1994; Robb Larkins 2015; Penglase 2014; Auyero and Swistun 2009; McCann 2013; Fischer, McCann and Auyero 2014). For admirable and important reasons, these studies often focus on the conditions of informal settlement as empirically existing phenomena for populations on the urban margins. Increasingly, scholars also note or examine the distinct modes of practice emergent from these spaces of collective historical and community significance. Possible solutions to the acute absence of centrally redistributed services within these areas have become pressing concerns central to everyday life. The ways in which ad hoc community-led solutions are cobbled together across a range of demands-security, transportation, governance, and housing for example-also reveal practices of organizational and associational life (Leeds 1994; Arias 2006; Goldstein 2004).

Still, how these spaces are actively produced by political authority in a larger system of empirical governance is much too narrowly theorized. Notably, the idea of state 'absence' as governance -- that populations are left to die as a matter of sovereign power (Agamben 1998; Mbembe 2003) -- has not informed empirical urban studies, especially in the Global South (Roy 2009). Some scholars have recently argued that we must consider the city as a larger whole, not merely as a collection of seemingly distinct, noteworthy, or problematic pieces (Arias 2006; Diken 2005). The prominent and systemically routinized existence of 'clones' of state institutions and practices signifies an important conceptual category in this regard. These replicas are spatial practices nonetheless at the centre of governance, unexceptional in their everyday existence within bureaucracies. In the state's tacit 
acceptance of these practices, it marks them as normal within routine political practice (Schmitt 1985).

The simultaneous incorporation of top-down and bottom-up practices into a larger system of political ordering recalls Weberian notions of administration, territory, and governance as qualities of the urban (Weber 1958). Such a system reflects empirical spatial practices that are not necessarily oppositional or antagonistic, as they can routinely seem. Rather, seemingly distinct spatial practices -- housing, urbanization, policing, justice, cloned cars, among many other possibilities -- are mutually produced, mutually productive, and complementary in their formation of a more or less stable pattern of governance. Together, facsimiles and their originals coexist and produce a particular format of administration, territory, and governance that incorporates rather than excludes spatial histories of exclusion and means of survival.

As an urban form, megacities are defined by seemingly distinct patterns of urbanization with long historical roots. As particular sites of governance and authority, cities embody the ways that the relative 'exclusion' of certain populations is central to the production of political order (Schmitt 1985; Agamben 1998). The existence of 'slums' as a particular manifestation of informal urbanization, for example, is indicative of authorities' abilities to produce and define what is considered normal (Roy 2009). While it is tempting to see informality as 'exceptional', it is not. The indignities of infrastructure absence, mundane police violence, and subhuman everyday conditions are systemic. On closer look, it is analytically impossible to separate the formal and the informal, or, in other words, to make one part of something that is profoundly normal, exceptional. Slums fall acutely into this 
category - that which is unexceptional, can be removed, violated, stripped of dignity without great resistance (Roy 2009). To demarcate informality as exceptional is to take a position that defies everyday practice.

The point I seek to make is that the indignities of precarious existence are desired by sovereign authority. Diken uses the film and Rio de Janeiro favela City of God to discuss the ways that urban sovereignty "works through the act of abandoning subjects" (2005: 309). While it is tempting to see the favela as an excluded space, that 'exclusion' is not outside the city, but rather, in its centre. It is the favela and both its real and perceived residents that cause the fortification of the city, the patterning of formal urban infrastructure, and mobility in the city. Das and Poole (2004) note that a consideration of the 'margins' allows us to see complete 'systems' that do not conform to the types of normative platforms (i.e. democracy, the oft-implied ideal state) that feature in many academic and policy discourses. Incisively, they point out "... consideration of the margins enables us to see how economic citizenship, rent extraction, and multiple regulatory regimes are necessary parts of the functioning of the state, much as the exception is necessary for the understanding of the law (2004: 21)." That which is unexceptional, mundane -no matter how trying- is systemically central.

To paraphrase Mbembe's (2003) work on the 'necropolitical,' marginal populations are central to the rationality of political order. Analytically, state action in territories or populations that seem exceptional, whether in the form of deadly police incursions in Rio de Janeiro, the redevelopment of Mumbai's port slum, or the massacring of 'cartel' populations in Juarez or Tijuana, should not be seen as evidence of state incapacity. These conditions 
must be seen as a logical extension of how certain populations, seemingly marginal but absolutely central, enable a particular modality of governance (Agamben 1998).

Unexceptional populations have unexceptional practices. The social practices of these unexceptional spaces and populations must similarly be understood as routine and normal. Devalued populations come to provide their own unremarkable forms of justice, infrastructure or informal institutional solutions that are, only exceptionally, questioned or attacked by the state. The results of longstanding neglect are what interest us here: the creation of alternative forms of order out of conditions of disorder, in ways that deeply integrate formal and informal bureaucracies, and as intertwined forms of everyday practice.

This is particularly clear when it comes to questions of violence. Take for example the range and reach of devalued populations who have come to recast the fundamental correlates of order in their own unique terms: prisoners (not administrators) in United States prisons making their conditions safe (Skarbek 2014); the Japanese Yakuza's 'honourable outlaws' creating rules to redefine life for many of the country's invisible and expendable ethnic Koreans and burakumin caste (Kaplan and Dubro 2012); El Salvador's maras signing truces that stop deadly violence overnight (Cruz and Duran-Martinez 2016); and São Paulo's Primeiro Comando da Capital (PCC) organizing crime group that keeps prisons stable and make the city as a whole less deadly (Denyer Willis 2015).

While it is easy to see gangs, organized crime, and lynch mobs as antagonistic to the larger established order-the formal and informal do spar violently on occasion, and more obviously at certain scales of analysis - both sets of actors often subscribe to the same logic 
with respect to who can (or should) be the subject of violence and why (Denyer Willis 2015; forthcoming). The consequence of such an alignment is that the formal and informal systems of justice come to co-exist as equally salient components in a larger system, producing - as it were-a single 'ecology' of policing or security. The formal public administration of violence reduction, though not always carried out by the bureaucracy of the state, nonetheless works similarly to the informal administration of security. Together, these practices suggest that the actions of devalued populations are central to a single logic of governance, even one dominated by formal state actions, both in terms of their systemic victimization of certain populations and in the nature of responses to victimization.

\section{The Clone: Revealing the Logics of the Informal Within the Formal}

Facsimiles, or "fakes" that reproduce the logic and order of the formal, are part and parcel of political authority and bureaucracy in São Paulo. They are mundane and uncontested for the most part. Take an example from ethnographic research that I carried out with police detectives of the Civil Police in local precincts:

One afternoon, during my research with the Civil Police in the neighborhood precincts of the city of São Paulo, Brazil, I sat with detectives as they collected and filed routine crime reports from citizens coming in off the street. In this precinct, in a decidedly orderly part of the city home to shopping malls, wide avenues, and a mix of tall apartment buildings and single family homes on well-planned streets, police saw much of the kind of crime that has become normal in this city: armed carjacking, armed robbery, fraud, and of course, many neighborhood squabbles. At a certain point, a man approached the counter looking entirely perplexed. He couldn't make sense of it. He took a seat at the counter, and recounted the 
reason he had come. Up until an hour or so prior, he had been enjoying an afternoon out with his family at the mall. They'd taken in a movie, strolled among the stores, and had a bite to eat alongside hundreds of others in the food court. When it was time to leave, they headed to the indoor parking lot, but when the man tried to open his car door, the key wouldn't go in the lock. It wouldn't open. He tried again. Confused, he stepped back, gazing at the car. It was the right color. It was the right model, but inside were belongings he didn't recognize. Feeling foolish, he walked back toward the aisle to look for a similar car that might be his.

Three spots down, he saw it, but still sheepish about his prior mistake, he eyed the first car as he walked away. To his surprise, the license plate number was the same as the one on the second car-his real car. Everything, it turned out, was the same, including the serial numbers on each dashboard and the shade of tint on the windows. And then it struck him: this is why l've been getting unexplained photo traffic tickets. The police detective listening to the story was curious and enjoyed the coincidence, but had heard it before. Still, bumping into your own car at the mall in a city of twenty million people was a new one.

To create a clone of a car down to such detail -- make, model and color --is a masterful feat requiring smarts and diligence. It can, however, be done relatively easily by matching a car by exterior appearance -for example, finding another car of the same make and model to match with a stolen car, potentially repainted and with the windows tinted. But more important is that even the paper registration documents, which travel with the car and plates, not the owner, were the same, including details like name of the chassis number, the model year, and taxes paid. And every cloned car has a new and identical license plate to 
match. This degree of duplication entails a degree of surreptitious influence, as though suggesting a startling ability to dig deep into the inner workings of a number of different agencies of law, regulation, and administration for data; and then creating identical copies of the bureaucratically certified documents, which are printed on special paper, and a license plate, plus a new serial number plate. It suggests a larger scale of production that can generate thousands of 'cloned' cars by means of vehicle robbery, information capture, body work, and the quiet replication of valid documents and existing license plates. After all, for one person to stumble upon his 'own' car in this urban region of twenty million residents defied the odds to an inexplicable degree. Or did it?

Disturbed and afraid, the man had called the so-called beat cops, or those with the power to police the urban quotidian, a power in Brazil that rests with the Military Police. They came and agreed to wait with the other car to see who would show up, vowing to bring them to the precinct if and when they appeared. And someone did. Just as the man had finished telling his story to the detectives in the station, the Military Police walked in. And they came with a man in tow. The man claimed that he'd borrowed the car from a friend, who had lent it to him for the week and was now out of town. He had no explanation for the two cars being identical, and as he pointed out, it was equally possible that the first man's car was the clone, not the one he had borrowed. Neither of them had the ownership documents, which authorities recommend you not keep in the car. He had the same vehicle registration papers and insurance documents, which he had given to the Military Police.

The detectives were intrigued, but already exhausted by the prospect of what paperwork such a case might entail. Strictly speaking, the man that the Military Police had brought in 
had not committed any crime yet, according to the detective. His documents seemed valid, and he was proving cooperative, even though they could neither prove that he was involved in making the car and using it routinely, nor that his friend hadn't been duped when he got a deal on a nice used car. In any case, the detectives had little interest in pursuing it further. The replication of so many meaningful bureaucratic documents and data, each of which would, if done according to the 'rules', entail months and many stages of tests, certifications, and taxes and fees, was daunting. And now, each of those documents, especially taken together, implicated the state bureaucracy itself, which was another reason not to make a big deal out of it. Something so apparently systemic would not be solved easily.

Eventually, the detective and his team decided they could do little except impound both cars for further investigation. There was no way to decide who was wrong and who was right in the case, and who was the victim, much less who had broken the law. That would need to be determined by a thorough analysis, carried out by the pericia (crime scene analysts), which would get to it in at least a few days in a search of doctored numbers on the chassis and elsewhere. In the meantime, the man who had stumbled upon his own car during his Sunday at the mall - if it was indeed his-would have to use a bus or call a friend or family to take him home with the police report in hand.

\section{Clones in the Context of Everyday Urbanism}

The cloning of cars is taken for granted in São Paulo, perhaps because of the city's size, complexity, and the ubiquity of the automobile in defining mobility and the larger ethos of urbanism. With cars a dominant actor in all city spaces, from the formally recognized to the 
informal, car cloning has become unexceptional, routine, and to a great degree, mundane in the sense that it may be the least of affronts that anger or worry citizens on a daily basis. In addition to the growing demand for car usage, some of this had to do with the workings of the state, or better said, the inadequate responses of formal state actors. Detectives who are technically responsible for repressing such a practice are laughably unable to respond. Likewise, efforts by citizens to exorcize themselves of their clones prove fruitless, particularly if they need to petition formal state agencies to do so.

Part of this owes to the fact that the state bureaucracy responsible for vehicle licensing and registration recognizes the widespread existence of clones, but imposes an extraordinary burden of proof (and documentation) on the part of 'victims' to move formal claims forward. And even when a citizen manages to extricate herself or himself of the consequences of the clone, the clone does not mystically stop existing or circulating in the city. The informal practice of creating bureaucratically certified cars cannot be suppressed by the bureaucracy that it impersonates. The practice and its outcomes have accordingly become a normal part of the formal bureaucracy and what it accepts as the status quo. Not even police conducting routine traffic stops are readily able to tell the difference.

The urban region of São Paulo has more than twenty million residents. In the city proper, however, residents comprise only slightly more than half of this number. Even so, during the day millions of people flow back and forth across otherwise indistinguishable administrative boundaries for work, study, and much else. For these reasons, there have been many efforts to make the city more accessible, orderly, and predictable, such as designating bus-only lanes, and instituting restrictions on private vehicle use. The city's Traffic Engineering 
Company (CET), a public institution, manages many of these efforts. Hundreds of traffic cameras and upwards of 1500 mobile workers detect a suite of violations that range from speeding to driving the wrong way on a street, using a protected lane, and using your car on its prohibited days. Using new technology applications like Camrite, we know that nearly all of these cameras are in the central and formally urbanized part of the city with the exception of arterial thoroughfares ${ }^{2}$.

Central to this is the city's traffic 'rodizio', a weekly system where private cars are restricted from accessing the central city during rush hour in the morning and evening, depending on the last number of their license plate ${ }^{3}$. On that day, affected residents must drive earlier, get on a bus, or take the metro. Cars that flout the rules are flagged by mobile traffic workers and stationary cameras, with the bills being sent to the vehicle's registered address with a note of the offense. Usually, this is how citizens come to know that their car has been 'cloned' -before they bump into it in a mall, on the street, or at a crosswalk (Gazeta 2011). The arrival of these bills, one after the other, is a sure sign. Take this example from a newspaper article in 2012 (Soares 2012):

A São Paulo driver who had his car cloned decided to take matters into his own hands after receiving more than 25 fines in five months, for infractions he didn't commit. On Thursday night, the $19^{\text {th }}$, Valter Soares, 30, set himself on the corner where the fines had accrued. He saw the 'double' and followed it. He then called the police, and subsequently discovered the identity of the driver of the car that was identical to his, including the license plate.

Soares spent nearly five hours waiting, with his own car, a 2009 Honda Civic, strategically parked. This was the fifteenth time he had tried to find the other car, on Avenida Salim Farah Maluf, in front of the Quarta Parada cemetery, on the West Side of the city. He knew that the Honda Civic that was causing him trouble would,

\footnotetext{
${ }^{2}$ This is a realtime crowdsourcing website, https://camerite.com.

${ }^{3}$ A similar rodizio exists for transport trucks.
} 
sooner or later, pass the spot. "Just in the month of August, I received fines every Wednesday, my rodizio day, at this one radar camera," he said.

He was sure because in an earlier "patrol" at the same spot, he saw the cloned car pass, but could keep up with it. Last Wednesday, he had more luck. At exactly 7:45 in the evening, the 'double' came past. Soares followed it to its destination: a university on Serrado Jaire avenue, in Freguesia do Ó, on the North Side. He called 190 for the Military Police, and with the arrival of the police, discovered that the person responsible for all of the fines was a university professor.

According to the police report, the driver of the cloned car affirmed that she was as much a victim as was Soares. She swore that she had purchased the car legally in December of 2011 , for $\mathrm{R} \$ 46,000$ ( $\$ 23,000$ USD at the time), and said that since then, had been trying to obtain the ownership documentation from the seller. For the Civil Police, the investigation will continue following a criminal inspection. They do know, according to the different numbers on the documents and the motor, that the cloned car was, in fact, the one in the possession of the professor.

Soares has said that, even if the story of the professor is true, he will take her to court. "She is responsible for the way that she drives. By the number of fines that I have received since May, and I only bought the car in March, it is clear that she does not follow traffic laws, much less the rules of the rodizio".

Soares also says he will sue the São Paulo Municipal Transport Secretariat (SMT), the body that he says he sought out more than 15 times. "I took them things proving that the car in the photo wasn't mine. There are differences in the model, tone of the wheels, on the grill and the headlight. I also sent them copies of the police report that I filed when I discovered that the car was cloned. All of those things were dismissed."

I had already taken the case to the police, to Detran, to SMT and no one helped. I had to take it into my own hands. It was perseverance. I was already thinking about using the car until it was worthless, and afterwards handing over to the government replete with fines," he said.

What makes this news report particularly interesting, beyond the fact that it was a university professor who was driving the clone, is the fact that it was written by the man himself. News coverage of cloned cars has become so humdrum that it is only made interesting by something novel (in this case, what this particularly well known newspaper calls "self reporting"). What is news here is not that clones exist, but that the individual went to extremes to find the car, actually did so, and after the discovery the individual personally wrote an article about it. 
Having said that, a preponderance of examples speak to the existence of clones as more routine than remarkable. One is a short and alluring video created and narrated by a journalist at one of the city's two big newspapers about his own personal tribulations. In the video, the reporter claims that he has been to the Department of Transit (Detran) office six times, and to a police station to file a criminal report. And yet, his requests for a resolution from these bureaucratic agencies are rebuffed at each turn. All the while, he keeps receiving fines in the mail, and his driver's license continues accruing demerit points, which could end with his license being revoked. It ends with a degree of personal resignation, having to tolerate a clone of his car circulating at will, apparently unhindered and unregulated, throughout the city (Estadao 2014) - yet paying its fines.

Even if clones have become mundane in everyday life and legitimized by a form of bureaucratic rationality despite their "informality," we still do not have figures for exactly how common they are. Police will not release figures, and Detran is generally resistant to the idea that they even exist. Even so, one report claimed that in a two-month period, 250 cloned cars were apprehended (Epoca n/d). This explains why, in São Paulo at least, few residents could say that they have not heard of clones and the associated problems they pose for legitimate owners. This state of consciousness also owes to the fact that there is a booming economy related to these activities. Media reports and some arrests connect the production of cloned cars to used car dealers on the East Side of the city. These dealers often line the secondary streets that reach outward from the central city, establishing their presence. São Paulo's dealers engage in a booming business, turning over vehicles to those who cannot afford new ones, either because they do not qualify for financing or have no 
credit. Used car dealers are middlemen of sorts, negotiating the boundaries between obtaining an important status symbol, accessing the economy, and mediating the contrasting demands of the formal versus informal economies. There is, of course, a huge demand for dealer-sold used cars, which, apart from being less expensive, often come with legal documentation, taxes paid, and meet other bureaucratic requirements, which have their own prerequisites of other regulated documentation. Used cars are sold both through formal dealers and their businesses, but also by dealers and private parties at temporary used car fairs, which are held weekly or a couple of days a week in large open lots, in areas where such space is available. Because of their relative brevity, there is pressure on both seller and buyer, and a remarkable turnover as a result. During my time accompanying homicide and other detectives, moreover, many a case traced circuitously through the sale and purchasing of used cars. Almost inevitably, the reported sale values of these used cars varied widely.

If cloned cars are exploding in number, it is not merely due to the uncertainty surrounding car ownership itself, but also to the scaling out of this trade across city space. According to the official statistics of the Secretary for Public Security, 99,047 cars were stolen in the city of São Paulo in 2014 alone. Put differently, 271 cars are stolen per day in the city proper of 11 million residents. While this number fluctuates by up to twenty thousand either way in a given year, there are at least 75,000 cars that are abandoned, quickly shipped to neighbouring countries, used to commit crimes, cut into pieces and resold, or simply reborn with a different identity. If only $10 \%$ of stolen cars are recreated as clones -- a very modest guess -- then 7,500 clones are added to the streets of São Paulo, every single year. 


\section{Discussion and Conclusion}

In this article, I have argued that subsumed within the city of São Paulo are a number of facsimiles of formal governance that flow from the built spaces and historical patterns of exclusion that mark state-society relations. Cloned cars illustrate how the social practices of devalued populations have become pervasive and indistinguishable from the practices of the formal authorities, or what we might consider the 'original' purveyors of social and spatial order. As such, they must be considered part of a larger system of governance and authority, not necessarily a deviation from it. They constitute examples of how bottom-up and top-down forms of administration coexist and come to constitute what is both bureaucratically mundane, but also oddly rational.

The normalcy of clones not only speaks to the inability of everyday bureaucrats to separate the 'informal' from the 'formal' - or the facsimiles from their originals -- in a meaningful way. It also suggests that they are connected phenomenon, at least the extent that the influence of the informal comes to dramatically alter the practices of the formal. Practically speaking, for police detectives this means that it is virtually impossible to distinguish who the victim is in a given case, at least without extensive investigation. But extensive investigation rarely happens meaningfully when cases proliferate (Denyer Willis 2014a). Moreover, there is often doubt whether some cloned cars are being used by those who have actually cloned them, or by people who know them to be cloned. Victims could also be those who unsuspectingly (but perhaps foolishly) bought them as used cars from dealers in the peripheral parts of the city or in auto fairs, where they are sold at prices below market value in order to maintain a quick turnover. For those without great purchasing power, 
buying a cloned car is one option among a suite of imperfect options for consumers -itself a form of negotiation between formality and informality.

The difficulties in distinguishing between the original and the facsimile help sustain the conclusions of scholarship that sees the city as a constitutive sum of all its parts under a larger system of authority. Especially in a place like São Paulo, where the realm of the informal is particularly prominent, it is foolish to only consider the local social problems of poor residents in marginalized neighbourhoods or districts in relative isolation, as though the margins are devoid of agency and without contrary flows of influence. The empirical practice of governance in São Paulo, seen though facsimiles like cloned cars, 'criminal criminal justice' (Denyer Willis 2015), and informal urbanization, reminds us that political authority does not float 'above' society and space. Governance is consumed and produced by populations and practices that make sense for given spaces, even those locations where an absence of the state seems to exists. Absence, in that sense, must be understood as a form of governance constructed through abandonment. But absence also gives rise to alternative ways of accessing the state. This is possible because that which emerges from perceived disorder, and on the part of under-valued populations, is assumed to be politically inconsequential by definition. And yet, it is precisely this assumptions of depleted value that give rise to facsimiles that are otherwise not presumed important. The self-ordering of spaces purposefully left 'to disorder' contributes to the constitution and reproduction of political order. This paradox has come to define the everyday practice of governance in São Paulo. 


\section{References}

Agamben, G. (1998). Homo sacer: Sovereign power and bare life. Palo Alto: Stanford University Press.

Arias, E. D. (2006). The Dynamics of Criminal Governance: Networks and Social Order in Rio de Janeiro. Journal of Latin American Studies, 38, 1-32.

Auyero, J. and Swistun, D. (2009). Flammable: Environmental Suffering in an Argentine Shantytown. Oxford: Oxford University Press.

Caldeira, T. (2000). City of Walls: Crime, Segregation and Citizenship in São Paulo. Berkeley: University of California Press.

Das, V., \& Poole, D. (2004). State and its margins: comparative ethnographies. Anthropology in the Margins of the State. Santa Fe: School of Advanced Research Press.

Davis, M. (2006). Planet of Slums. London: Verso.

Davis, D. E. (1999). The Power of Distance: Rethinking Social Movements in Latin America. Theory and Society, 24(4), 589-643.

Denyer Willis, G. (2014a) The Gun Library. Boston Review. Retrieved from: http://www.bostonreview.net/world/graham-denyer-willis-pcc-gun-library-São-pauloprisons-crime

Denyer Willis, G. (2014b). Antagonistic authorities and the civil police in São Paulo, Brazil. Latin American Research Review, 49(1), 3-22.

Denyer Willis, G. (2015). The Killing Consensus: Police, Organized Crime and the Regulation of Life and Death in Urban Brazil. Berkeley: University of California Press.

Denyer Willis, G. (forthcoming). In: Loader, I, Bradford, B., Steinberg, J., and Jauregui, B. Handbook on Global Policing. Oxford: Sage

Diken, B. (2005). City of God. City, 9(3), 307-320.

Cruz, J. and Duran-Martinez, A. (2016) Hiding Violence to Deal with the State: Criminal Pacts in El Salvador and Medellin. Journal of Peace Research, 53(2), 197-2010.

Epoca. (n/d) Polícia investiga aumento de carros clonados em SP. Retrieved from: http://revistaepoca.globo.com/Revista/Epoca/0,EDR51616-6014,00.html

Estadao. (2014). A saga de quem teve um carro clonado em sp. O Estado de São Paulo. Retrieved from: http://São-paulo.estadao.com.br/noticias/geral,a-saga-de-quemteve-um-carro-clonado-em-sp-imp-,1125680 
Fischer, B., McCann, B., \& Auyero, J. (Eds.). (2014). Cities from Scratch: Poverty and Informality in Urban Latin America. Duke University Press.

Gay, R. (1994). Popular Organization and Democracy in Rio de Janeiro: A Tale of Two Favelas. Philadelphia: Temple University Press.

Gazeta (2011) Motorista persegue carro clonado e chama a polícia em SP. Retrieved from: http://www.gazetadopovo.com.br/vida-e-cidadania/motorista-persegue-carroclonado-e-chama-a-policia-em-sp-b9h2w6w2nsy0jrlcskzlgwnke

Gilbert, A. (2007). The return of the slum: does language matter? International Journal of Urban and Regional Research, 31(4), 697-713.

Goldstein, D. M. (2004). The spectacular city: Violence and performance in urban Bolivia. Duke University Press.

Kaplan, D. E., \& Dubro, A. (2012). Yakuza: Japan's criminal underworld. Berkeley: University of California Press.

Lefebvre, H. (1992). The Production of Space. Oxford: Wiley.

Harvey, D. (1972). Social Justice in the City. Baltimore: Johns Hopkins University Press.

Mbembe, J. (2003). Necropolitics. Public culture, 15(1), 11-40.

Roy, A. and AlSayyad, N. (2004). Urban Informality: Transnational Perspectives from the Middle East, Latin America, and South Asia. Lanham, MD: Lexington.

Roy, A. (2005). Urban informality: Toward an epistemology of planning. Journal of the American Planning Association, 71(2), 147-158.

Roy, A. (2009). Why India cannot plan its cities: informality, insurgence and the idiom of urbanization. Planning theory, 8(1), 76-87.

Schmitt, C. (1985). Political Theology. Cambridge, MA: MIT Press.

Skarbek, D. (2014). The Social Order of the Underworld: How Prison Gangs Govern the American Penal System. New York: Oxford University Press.

Soares, Valter. (2012). Motorista encontra clone do próprio carro em São Paulo. Terra Online. Retrieved from: http://noticias.terra.com.br/brasil/transito/vc-reportermotorista-encontra-clone-do-proprio-carro-emsp,750ce7948c1da310VgnCLD200000bbcceb0aRCRD.html

Wacquant, L. (2008).Urban Outcasts. Malden, MA: Polity Press. 
Weber, M. (1958). The city (pp. 65-89). In D. Martindale, \& G. Neuwirth (Eds.). New York: Free Press. 